Aims Clear guidelines exist for the management of major haemorrhage in adults. These include a strong emphasis on early transfusion of Fresh Frozen Plasma (FFP) in conjunction with Packed Red Cells (PRC) in order to avoid/treat possible accompanying coagulopathy. Current practice within the local neonatal population is to await clotting profiles and administer FFP if coagulation is found to be abnormal. This practice may lead to a significant delay in treatment. The aim of this service evaulation was to identify whether term neonates with major haemorrhage around the time of delivery required support with coagulation factors. This may support the use of prophylactic FFP alongside $\mathrm{RBC}$ transfusion prior to results becoming available helping to stabilise the infant sooner.

Methods Data was requested from our local blood transfusion laboratory for all requests for blood products made for patients on the neonatal unit between April 2011 to December 2013. Further details regarding antenatal and neonatal course were then taken from the Badger database on all babies that were identified to have received blood products on their date of birth or following day. Babies born at less than 37 weeks were excluded.

Results We identified 7 term babies with a clear history of major perinatal blood loss. $5 / 7$ (71\%) required transfusion of FFP in addition to PRC on the basis of abnormal clotting profile. All babies receiving FFP needed extensive resuscitation at birth followed by intensive care support, whereas the 2 babies that were not transfused were clinically stable. One of the babies not receiving FFP did not have their clotting profile checked. All babies received Vitamin $\mathrm{K}$ post delivery as standard.

Conclusion Term infants with a clear history of perinatal blood loss who are compromised at delivery and require packed red cell transfusion should be considered for early transfusion of FFP without awaiting coagulation profiles.

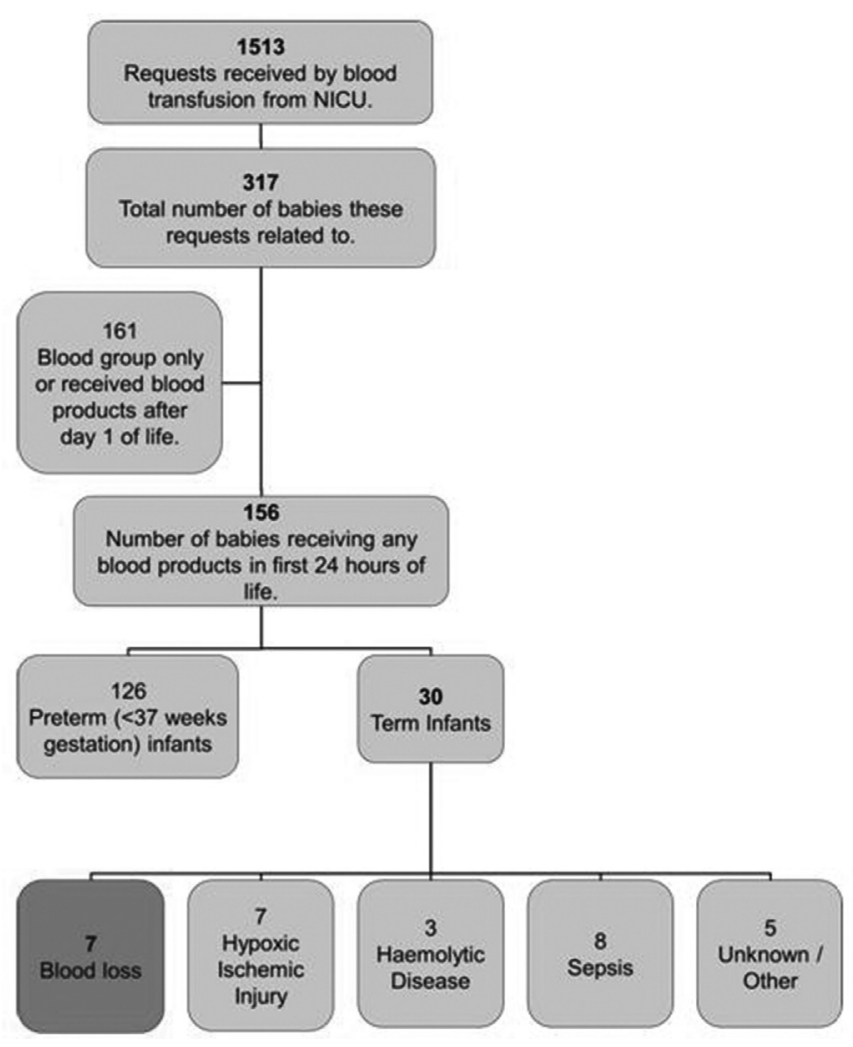

Abstract G121(P) Figure 1 Participant flow diagram

\section{G122(P) MELATONIN AND IMMUNE CELL RESPONSES IN NEONATAL ENCEPHALOPATHY}

${ }^{1} S$ Asalm, ${ }^{2}$ RWG Watson, ${ }^{2}$ A O'Neill, 3,4,5EJ Molloy. ${ }^{1}$ Neonatology, National Maternity Hospital, Holles Street, Dublin, Ireland; ${ }^{2}$ Conway Institute for Biomolecular and Biomedical Science, University College Dublin, Dublin, Ireland; ${ }^{3}$ Neonatology, Our Lady's Children's Hospital, Crumlin, Ireland; ${ }^{4}$ Academic Paediatrics, Trinity College Dublin, National Children's Hospital, Tallaght, Ireland; 'PPaediatrics, Coombe Women's and Infant's University Hospital, Dublin, Ireland

\subsection{6/archdischild-2015-308599.121}

Introduction Infection and inflammation can be antecedents of Neonatal Encephalopathy (NE) and increase the risk of neurological sequelae. Melatonin is a potent immunomodulator and antioxidant (1) and may alter the systemic inflammatory response in NE (2).

Aim To investigate the in vitro effect of melatoninon whole blood reactive oxygen intermediates (ROI), CD11b and Toll-like receptor (TLR)-4 in neutrophils and monocytes from infants with NE receiving therapeutic hypothermia (TH) versus healthy neonatal controls in the first week of life.

Methods Infants with NE were recruited and their demographics details, grade of NE, MRI results, outcome and placental histology were recorded. Whole blood was taken on Day 1,3 and 7 of life (NE group) and day 1(Controls) and flow cytometry used to assess TLR4, CD11b and ROI in both monocytes and neutrophils in the presence of Lipopolysaccharide (LPS) and/or melatonin. Ethics was received from ethics committee at National Maternity Hospital.

Results LPS-induced ROI production was significantly increased in both neutrophils and monocytes $(\mathrm{p}=0.03)$ in NE versus controls $(n=6)$ on day 1 of life. On day 7 of life, following $\mathrm{TH}$, LPS-induced CD11b upregulation was significantly decreased by melatonin in vitro in neonates with NE $(n=7)$. There was no difference in TLR4 expression in NE and controls.

Conclusion Melatonin decreases the production of CD11b in neutrophils, which is a marker of neutrophil activation and migration and may ameliorate the augmented systemic inflammatory response seen in infants with NE.

\section{G123(P) SURVEY OF DELIVERY ROOM PRACTICE: RESUSCITATION OF EXTREME PRETERM INFANTS}

S Al-Jilaihawi, A Huertas-Ceballos. Neonatal Department, University College Hospital, London, UK

\subsection{6/archdischild-2015-308599.122}

Aims There are Nuffield Guidelines in place to aid clinicians in their decision-making in the resuscitation of extreme preterm infants. This remains an area where there is varied practice nationally and internationally, and decisions are often case dependant. We sought to survey a cohort of Consultant Paediatricians involved in neonatal resuscitation on their approach to the resuscitation of extreme preterm infants, to assess current attitudes to practice.

Methods A questionnaire was designed using an online survey programme, modelled on the Nuffield guidance for resuscitation of extreme preterm infants. This was distributed to a group of Consultants via email and results were collated using the online programme.

Results 45 of 68 (66\%) Consultants completed the survey. 26\% of responders were from level 3 neonatal intensive care units (NICU), 62\% from level 2 units and 12\% from level 1 units. 
Abstract G121(P) Table 1 Results of data collection

\begin{tabular}{|c|c|c|c|c|c|c|}
\hline $\begin{array}{l}\text { Baby } \\
\text { Num }\end{array}$ & $\begin{array}{l}\text { Gender } \\
\text { Weight }\end{array}$ & $\begin{array}{l}\text { Antenatal } \\
\text { History }\end{array}$ & $\begin{array}{l}\text { Initial } \\
\text { FBC }\end{array}$ & $\begin{array}{l}\text { Initial } \\
\text { Clotting }\end{array}$ & $\begin{array}{l}\text { Age Blood } \\
\text { Products } \\
\text { Required } \\
1=20 \mathrm{mls} / \mathrm{kg}\end{array}$ & Outcome \\
\hline 1 & $\begin{array}{l}\text { Male } \\
4000 \mathrm{~g}\end{array}$ & $\begin{array}{l}\text { Born through thick meconium. Umbilicus } \\
\text { not clamped correctly with blood } \\
\text { loss (estimated } 50 \mathrm{mls} \text { ) from cord. } \\
\text { Required intubation and ventilation on } \\
\text { delivery suite. }\end{array}$ & $\begin{array}{l}\text { Hb15.8Plt } \\
179\end{array}$ & $\begin{array}{l}\text { PT } 27.8 \\
\text { INR } 2.8, \\
\text { APTT 29.4, } \\
\text { Fibr } 1.3\end{array}$ & $\begin{array}{l}40 \text { mins - } \\
1 \text { RBC } \\
6 \text { hrs - } 1 \text { FFP }\end{array}$ & $\begin{array}{l}\text { Meconium Aspiration required iNO and transfer } \\
\text { for ECMO. No further blood product support } \\
\text { required after initial correction. Discharged } \\
\text { home at } 6 \text { weeks old. }\end{array}$ \\
\hline 2 & $\begin{array}{l}\text { Female } \\
3460 \mathrm{~g}\end{array}$ & $\begin{array}{l}\text { Large antepartum haemorrhage due to vasa } \\
\text { previa. Fetal bradycardia so emergency } \\
\text { C-Section performed. Intubated and } \\
\text { ventilated on delivery suite. }\end{array}$ & $\begin{array}{l}\text { Hb13.1 } \\
\text { Plt } 66\end{array}$ & $\begin{array}{l}\text { PT } 49.4 \\
\text { INR } 5.5 \\
\text { APTT } 100.8 \\
\text { Fibr }<1.8\end{array}$ & $\begin{array}{l}7 \text { hrs }-1 \text { RBC } \\
11 \text { hrs }-2 \text { Plt } \\
13 \text { hrs - 1FFP }\end{array}$ & $\begin{array}{l}\text { Poor condition at birth secondary to fetal blood loss. } \\
\text { Fluid resuscitated with saline and blood. Clotting factors } \\
\text { given following abnormal results. Therapeutically cooled } \\
\text { and discharged home at } 3 \text { weeks of age. }\end{array}$ \\
\hline 3 & $\begin{array}{l}\text { Male } \\
3550 \mathrm{~g}\end{array}$ & $\begin{array}{l}\text { Fetal bradycardia following large APH. Delivered } \\
\text { following emergency C-Section. Required full } \\
\text { resuscitation with intubation, chest compressions, } \\
\text { adrenaline and emergency blood. }\end{array}$ & $\begin{array}{l}\text { Hb19.9 } \\
\text { Plt } 96\end{array}$ & $\begin{array}{l}\text { PT } 19.3 \\
\text { INR } 1.9 \\
\text { APTT } 41.1 \\
\text { Fibr } 1.2\end{array}$ & $\begin{array}{l}20 \text { mins - RBC } \\
8 \text { hrs - } 2 \text { FFP } \\
19 \text { hrs - } 1 \\
\text { Cryo, } \\
30 \text { hrs - Plt }\end{array}$ & $\begin{array}{l}\text { Severe coagulopathy requiring multiple corrections } \\
\text { over first } 4 \text { days of life. Transferred for surgical } \\
\text { care at } 6 \text { days of age due to bowel perforation. }\end{array}$ \\
\hline 4 & $\begin{array}{l}\text { Male } \\
2295 g\end{array}$ & $\begin{array}{l}\text { Cord snapped during delivery } \\
\text { in pool with unknown } \\
\text { volume of blood loss prior to manual clamping. } \\
\text { Responded to ventilation breaths but very pale } \\
\text { so transferred to NICU. }\end{array}$ & $\begin{array}{l}\text { Hb11.8 } \\
\text { Plt } 83\end{array}$ & $\begin{array}{l}\text { PT } 12.7 \\
\text { INR } 1.2 \\
\text { APTT } 28.4 \\
\text { Fibr } 1.3\end{array}$ & 9 hrs - RBC & Short admission for monitoring and transfusion. \\
\hline 5 & $\begin{array}{l}\text { Female } \\
3435 \mathrm{~g}\end{array}$ & $\begin{array}{l}\text { Born via Emergency C-Section for Antepartum } \\
\text { Haemorrhage and fetal bradycardia. Required full } \\
\text { resuscitation with intubation chest compressions, } \\
\text { emergency blood and adrenaline. }\end{array}$ & $\begin{array}{l}\text { Hb } 16.1 \mathrm{Plt} \\
110\end{array}$ & $\begin{array}{l}\text { PT } 20.3 \\
\text { INR } 2 \\
\text { APTT >135 } \\
\text { Fibr } 0.9\end{array}$ & $\begin{array}{l}20 \text { mins - RBC } \\
5 \text { hrs - RBC, } \\
\text { FFP and cryo } \\
12 \text { hrs - FFP }\end{array}$ & $\begin{array}{l}\text { Deteriorated from day } 2 \text { of life with widespread } \\
\text { organ dysfunction and bradycardias. Reorientation } \\
\text { of care, sadly passed away on day } 3 \text { of life. }\end{array}$ \\
\hline 6 & $\begin{array}{l}\text { Female } \\
3748 \mathrm{~g}\end{array}$ & $\begin{array}{l}\text { Emergency C-Section following failed forceps } \\
\text { delivery. Born with poor perfusion and noted } \\
\text { to have large subgalial bleed. }\end{array}$ & $\begin{array}{l}\text { Hb } 13.0 \text { Plt } \\
249\end{array}$ & $\begin{array}{l}\text { Clotting } \\
\text { Screen } \\
\text { not Performed }\end{array}$ & $\begin{array}{l}1 \mathrm{hr}-\mathrm{RBC} \\
14 \mathrm{hrs}-\mathrm{RBC}\end{array}$ & $\begin{array}{l}\text { Stabilised following transfusion required short stay } \\
\text { for monitoring of OFC and establishing feeds. }\end{array}$ \\
\hline 7 & $\begin{array}{l}\text { Female } \\
3680 \mathrm{~g}\end{array}$ & $\begin{array}{l}\text { Artificial rupture of membranes - frank blood. } \\
\text { Fetal bradycardia then lost heart rate prior to } \\
\text { emergency C-Section. Required extensive } \\
\text { resuscitation at delivery, first heart rate at } 17 \\
\text { mins }\end{array}$ & $\begin{array}{l}\text { Hb } 122 \\
\text { Plt } 108\end{array}$ & $\begin{array}{l}\text { PT } 17 \\
\text { INR } 1.6 \\
\text { APTT } 123.1 \\
\text { Fibr } 1.0\end{array}$ & $\begin{array}{l}25 \text { mins - RBC. } \\
7 \mathrm{hrs}-\mathrm{FFP} \\
18 \mathrm{hrs}-2 \times \\
\text { RBC } \\
20 \mathrm{hrs}-\text { CRYO. }\end{array}$ & $\begin{array}{l}\text { Severe HIE, multiorgan failure. Transferred to PICU } \\
\text { for dialysis and laparotomy due to intestinal } \\
\text { perforation. }\end{array}$ \\
\hline
\end{tabular}

$91 \%$ of responders would always offer intensive care with the intention of admitting to NICU at 25 weeks gestation and above, compared to $58 \%$ at 24 weeks and $6.8 \%$ at 23 weeks gestation. At 24 weeks, $38 \%$ of responders would make the decision of whether to resuscitate based on the infant's initial clinical condition compared to $61 \%$ at 23 weeks. For 23 weeks gestation infants, giving precedence to parents' wishes (57\%) and weighing the baby before commencing resuscitation (32\%) were highest. At 22 weeks, $58 \%$ of responders would not resuscitate and $29 \%$ would not attend the delivery.

Conclusion There were varied responses at every gestation. Whilst the majority of 25 week and above gestation infants are offered full intensive care in accordance with Nuffield guidance, this was not the case for 24 week gestation infants. Initial clinical condition and response to initial resuscitation at birth play a larger role in decision making at 23 and 24 weeks. Parents' wishes and birthweight are more significant factors in decision making at 23 weeks. The varying attitudes to practice at each gestation highlight the challenges in following guidelines in the resuscitation of extreme preterm infants. This calls into question whether there is a need for more consensus.

\section{G124(P) IS IT TIME TO ENFORCE RIGOROUS INFECTION CONTROL GUIDELINES FOR VISITORS ATTENDING THE NEONATAL INTENSIVE CARE UNIT?}

H Yaseen, H Yaseen, U El-Kafrawy. Neonatal Intensive Care Unit, Bolton NHS Foundation Trust, Bolton, UK

\subsection{6/archdischild-2015-308599.123}

Nosocomial infections remain a major issue in neonatal intensive care units (NICU). This is related to numerous factors including, impaired immunity, fragile skin, and invasive lines. The impact of healthcare workers on infection transmission has been well documented, however little work has looked at the risk posed by visitors who frequently handle infants on NICU. 